\title{
Identification of Monilinia fructigena, M. fructicola, M. laxa, and Monilia polystroma on Inoculated and Naturally Infected Fruit Using Multiplex PCR
}

\author{
Marie-José Côté, Canadian Food Inspection Agency, Ottawa Laboratory (Fallowfield), Centre for Plant Quarantine \\ Pests, 3851 Fallowfield Road, Ottawa, Ontario, Canada, K2H 8P9; Marie-Claude Tardif, Health Canada, Food Di- \\ rectorate, Building \#7, Tunney's Pasture, P.L. 0700E1, Ottawa, Ontario, Canada K1A 0L2; and Allison J. Meldrum, \\ Canadian Food Inspection Agency, Ottawa Laboratory (Fallowfield), Centre for Plant Quarantine Pests, 3851 Fallow- \\ field Road, Ottawa, Ontario, Canada, K2H 8P9
}

\begin{abstract}
Côté, M.-J., Tardif, M.-C., and Meldrum, A. J. 2004. Identification of Monilinia fructigena, M. fructicola, M. laxa, and Monilia polystroma on inoculated and naturally infected fruit using multiplex PCR. Plant Dis. 88:1219-1225.

Monilinia fructigena, M. fructicola, M. laxa, and Monilia polystroma each have a different regulatory status. To monitor imported and exported fruit for the presence of quarantined Monilinia or Monilia species, a timely identification method is required. Random amplified polymorphic DNA analysis was used to generate an $M$. fructigena-specific band that was characterized by sequencing. Using the sequence obtained, primers were designed to amplify bands in the same genomic region of M. fructicola and M. laxa. These bands were also characterized by sequencing. From all three sequences, a multiplex polymerase chain reaction (PCR) method based on a common reverse primer (MO368-5) and three species-specific forward primers (MO368-8R, MO368-10R, and Laxa-R2) was established for the differentiation of the three Monilinia species. The multiplex PCR was tested with additional isolates and consistently produced a 402-bp PCR product for $M$. fructigena, a 535-bp product for $M$. fructicola, and a 351-bp product for $M$. laxa. The method was also used with isolates of the recently characterized Monilia polystroma, and all isolates amplified a 425-bp PCR product. The identification method was shown to amplify a PCR product directly from inoculated apples, and the PCR band produced was specific to the inoculated Monilinia or Monilia species. Furthermore, the multiplex PCR was used to identify Monilinia species on naturally infected stone fruits. The method correctly identified infections by both $M$. laxa and M. fructicola by successful amplification of corresponding PCR products for each species.
\end{abstract}

Additional keywords: brown rot, sequence characterized amplified region

Three Monilinia species cause brown rot of fruit. M. fructicola (G. Wint.) Honey and M. laxa (Aderhold \& Ruhland) Honey attack mainly stone fruits. The third species, M. fructigena Honey in Whetzel, also attacks stone fruits but is found more frequently in pome fruits (1). Recently, based on morphological, biological, and genetic differences between European and Japanese isolates of $M$. fructigena, van Leeuwen et al. proposed that the Japanese isolates be considered a distinct species named Monilia polystroma van Leeuwen (17). M. fructigena and M. laxa have traditionally been considered Old World species. However, recent isolations of M. laxa suggest it has a more global distribution (1). M. fructicola is considered a New World species, whereas Monilia polystroma has to date been found only in Ja-

Corresponding author: M.-J. Côté

E-mail: cotemj@inspection.gc.ca

Accepted for publication 18 June 2004.

Publication no. D-2004-0825-01R

(C) 2004 The American Phytopathological Society pan (17). In North America, brown rot of fruit is mainly caused by M. fructicola and to a lesser extent by M. laxa. In Europe, the main causal agents of the disease are $M$. fructigena and M. laxa (3). The identification of the three Monilinia species and Monilia polystroma relies on few morphological characteristics, and identification in culture is difficult, since their appearances vary from isolate to isolate within species (15). An identification protocol based on quantitative cultural and morphological features was established and requires up to 5 days $(17,18)$. To prevent the entry of $M$. fructigena or Monilia polystroma into North America and entry of $M$. fructicola into Europe, a more timely method is needed to differentiate the four species without having to culture the fungi.

Among many efforts to establish a molecular method for the differentiation of Monilinia species, Fulton and Brown (6) located a group I intron in the ribosomal small subunit (SSU) gene of M. fructicola. Polymerase chain reaction (PCR) primers for the M. fructicola SSU rDNA intron and some of the SSU sequence were developed for species identification (6). Recently, there have been reports showing that the intron-containing PCR product is not amplified in some isolates of $M$. fructicola, suggesting that some isolates lack the intron $(4,5,7,9)$. This observation means the species identification method is no longer reliable. The sequences of the ribosomal internal transcribed spacer (ITS) regions of the three Monilinia species and of Monilia polystroma have been reported, and sequence comparison reveals a high level of similarity $(7,8)$. Several molecular methods for the identification of Monilinia species are either based solely on ITS sequence variations or combined with other genetic markers $(5,10,16)$. Other molecular identification methods based on unique speciesspecific repetitive sequences and on a microsatellite region were also developed $(2,11)$. Some of the methods described have been developed and tested only with two of the three Monilinia species, whereas other methods present a result for only one species and do not identify the other species $(2,5,11,16)$. Yet another method presents a result for all three Monilinia species but produces PCR amplicons of the same size so that three PCR reactions have to be performed in order to identify the species (10). No method has been developed for the differentiation of all three Monilinia species and Monilia polystroma.

Random amplified polymorphic DNA (RAPD) analysis has been used to identify DNA polymorphisms between genomes $(19,21)$. Generating information from a RAPD fragment for the design of specific primers is an alternative technique used when sequences, such as ribosomal ITS regions, are very conserved and restrict the design of a species-specific PCR method. The objective of this work was to use the RAPD technique to identify polymorphisms among $M$. fructigena, $M$. fructicola, and M. laxa and to use the sequence information obtained from the RAPD polymorphic band to design species-specific primers for a multiplex PCR assay that would, in a single tube reaction, discriminate among the three Monilinia pathogens on inoculated apples and naturally infected stone fruits. The assay was further enhanced to enable the discrimination of Monilia polystroma from all three Monilinia species, including the closely related M. fructigena. 


\section{MATERIALS AND METHODS}

Fungal isolates. All isolates used and their sources are listed in Table 1. Cultures were received lyophilized and therefore were rehydrated before transferring to potato dextrose agar plates $(39 \mathrm{~g} / \mathrm{liter})$. In order to limit the presence of contaminating potato DNA from the culture media, DNA extractions were done from mycelia that had grown over glass coverslips which

Table 1. Monilinia and Monilia species, their origins, and multiplex polymerase chain reaction (PCR) results

\begin{tabular}{|c|c|c|c|}
\hline Species & Isolate no. $^{\mathbf{a}}$ & $\begin{array}{c}\text { Origin } \\
\text { (host, country) }\end{array}$ & $\begin{array}{c}\text { PCR product } \\
\text { (bp) }\end{array}$ \\
\hline \multirow[t]{11}{*}{ Monilinia fructigena } & ATCC 11790 & Unknown & 402 \\
\hline & ATCC 24976 & Apple, U.K. & 402 \\
\hline & ATCC 26106 & Pome fruit, England & 402 \\
\hline & ATCC 38358 & Pear, unknown & 402 \\
\hline & ATCC 48167 & Unknown, U.K. & 402 \\
\hline & CBS 231.57 & Pear, Netherlands & 402 \\
\hline & CBS 494.50 & Cherry, Netherlands & 402 \\
\hline & LMK 433 & Apple, Norway & 402 \\
\hline & LMK 434 & Apple, Norway & 402 \\
\hline & MUCL 570 & Crab apple, Belgium & 402 \\
\hline & NRRL 22703 & Pear, Belgium & 402 \\
\hline \multirow[t]{3}{*}{ Monilia polystroma } & CBS 102686 (Jap 1815) & Apple, Japan & 425 \\
\hline & CBS 102687 (Jap 2314) & Apple, Japan & 425 \\
\hline & CBS 102688 (Jap 2316) & Apple, Japan & 425 \\
\hline \multirow[t]{17}{*}{ Monilinia fructicola } & ATCC 42248 & Peach, New Zealand & 535 \\
\hline & ATCC 46606 & Peach, U.S. & 535 \\
\hline & ATCC 62879 & Prune, U.S. & 535 \\
\hline & CD 6 & Sweet cherry, Canada & 535 \\
\hline & CD 7 & Sweet cherry, Canada & 535 \\
\hline & CPQP 1 & Peach, Canada & 535 \\
\hline & CPQP 3 & Nectarine, Canada & 535 \\
\hline & DAOM 110195 & Cherry, Canada & 535 \\
\hline & DAOM 144446 & Plum Queen Anne, Canada & 535 \\
\hline & DAOM 144721 & Plum, Canada & 535 \\
\hline & DAOM 186890 & Unknown, Canada & 535 \\
\hline & JN Mer3-4 (DAOM 208461) & Peach, Canada & 535 \\
\hline & JN TC3-13 (DAOM 208464) & Peach, Canada & 535 \\
\hline & JN AN3-6 (DAOM 208467) & Peach, Canada & 535 \\
\hline & NRRL A-28151 & Peach, Canada & 535 \\
\hline & URY 2 & Unknown, Uruguay & 535 \\
\hline & URY 8 & Unknown, Uruguay & 535 \\
\hline \multirow[t]{15}{*}{ Monilinia laxa } & ATCC 9961 & Apricot, unknown & 351 \\
\hline & ATCC 32671 & Nectarine, U.S. & 351 \\
\hline & ATCC 62881 & Plum, U.S. & 351 \\
\hline & ATCC 66106 & Apricot, Spain & 351 \\
\hline & CBS 165.24 & Quince, unknown & $535^{\mathrm{b}}$ \\
\hline & CBS 202.25 & Pear, U.S. & 351 \\
\hline & CBS 298.31 & Apple, Ireland & 351 \\
\hline & CBS 488.50 & Peach, Netherlands & 351 \\
\hline & DAOM 209913 & Peach, unknown & $535^{\mathrm{b}}$ \\
\hline & LMK 656 & Unknown, Norway & 351 \\
\hline & LMK 723 & Nectarine, Italy & 351 \\
\hline & MUCL 18236 & Peach, Belgium & 351 \\
\hline & MUCL 30841 & Peach, Belgium & 351 \\
\hline & UAMH 3523 & Plum, Canada & $535^{\mathrm{b}}$ \\
\hline & UAMH 4801 & Cherry, Canada & 351 \\
\hline Monilinia demissa & CBS 151.22 & Chokecherry, unknown & $--{ }^{c}$ \\
\hline Monilinia mespili & CBS 139.23 & Medlar, Netherlands & --- \\
\hline Monilinia padi & ATCC 58545 & Chokecherry, U.S. & --- \\
\hline \multirow[t]{2}{*}{ Monilinia seaveri } & DAOM 43511 & Prunus spp., Canada & --- \\
\hline & DAOM 91807 & Wild cherry, Canada & --- \\
\hline Botrytis cinerea & DAOM 189076 & Potato, Canada & --- \\
\hline $\begin{array}{l}\text { Sclerotinia } \\
\text { sclerotiorum }\end{array}$ & DAOM 138182 & Apple, Canada & --- \\
\hline
\end{tabular}

a ATCC strains are maintained by the American Type Culture Collection, CBS isolates by the Centraalbureau voor Schimmelcultures, CPQP and CD isolates of Monilinia are from our laboratory and were identified by George P. White. DAOM isolates are maintained by the Canadian Collection of Fungal Cultures (Agriculture and Agri-Food Canada), JN isolates were obtained from John Northover (Agriculture and Agri-Food Canada, Research Farm, Vineland, Ontario, Canada), LMK isolates from Linda M. Kohn (University of Toronto, Toronto, Ontario, Canada), MUCL isolates by the Mycotèque de l'Université Catholique de Louvain, NRRL isolates are maintained by the USDA Agricultural Research Service Culture Collection, UAMH isolates by the University of Alberta Devonian Botanic Garden, Canada, and URY isolates were provided by Pedro Mondino (Catedra de Fitopatologia, Montevideo, Uruguay).

b Isolates originally identified as M. laxa, correctly identified as M. fructicola by PCR.

c No PCR product.

had been deposited on the culture media surface.

Naturally infected fruits. Cherries, nectarines, and peaches showing symptoms of brown rot were used for the multiplex PCR. Half of each localized rotting area on the fruit was removed and put into a microtube. The sample was then either stored at $-80^{\circ} \mathrm{C}$ or processed for DNA extraction.

Apple inoculations. Asymptomatic apples were chosen for inoculation experiments for ease of use and year-round availability (J. Northover, personal communication). Apples were surfacesterilized with a $0.5 \%(\mathrm{vol} / \mathrm{vol})$ sodium hypochlorite solution. Three apples were inoculated at one or two sites per experiment. At each inoculation site, three incisions of $5 \mathrm{~mm}$ and at 90 degrees to each other forming a $U$ shape were made on the apple surface, leaving an uncut side acting as a hinge allowing the piece of tissue to be attached to the fruit. Inoculation sites for mixed infections were 30 to $40 \mathrm{~mm}$ apart. A piece of the apple skin was lifted, and a $4 \times 4 \mathrm{~mm}$ piece of agar plug with mycelia from a 1- to 6-month-old potato dextrose agar culture was inserted. Isolates used for inoculation were M. fructicola ATCC 42248, M. fructigena ATCC 26106, M. laxa ATCC 9961, and Monilia polystroma CBS 102686. Replicate apples for each inoculation experiment were incubated together in a sealed container. One sealed container was used per species or mixed species experiment to prevent contamination from other fungi. Cubic pieces of apples (skin and flesh) approximately 5 $\times 5 \mathrm{~mm}$ square were harvested at 7 to 10 days after inoculation.

DNA extractions. DNA was extracted following the method of Möller et al. (14) with modifications. Mycelia were rinsed off the glass coverslip with $550 \mu \mathrm{l}$ of extraction buffer $(100 \mathrm{mM}$ Tris- $\mathrm{HCl}, \mathrm{pH} 8.0$, $10 \mathrm{mM}$ EDTA, 2\% sodium dodecyl sulfate [SDS]) into a $1.5-\mathrm{ml}$ microcentrifuge tube and crushed with a disposable pestle in a microtube. Apple samples or $100 \mu \mathrm{l}$ of flesh taken from the infected area of stone fruit were placed in a $1.5-\mathrm{ml}$ microcentrifuge tube with $550 \mu \mathrm{l}$ of extraction buffer and crushed with a disposable pestle in a microtube. Proteinase K $(100 \mu \mathrm{g})$ (Roche Diagnostics, Laval, QC, Canada) was then added to the mixture and incubated at 55 to $60^{\circ} \mathrm{C}$ for $60 \mathrm{~min}$. The mixture was vortexed twice during the incubation period. After incubation, $140 \mu \mathrm{l}$ of $5 \mathrm{~N} \mathrm{NaCl}$ was added, followed by $65 \mu \mathrm{l}$ of $10 \%$ CTAB (hexadecyltrimethylammonium bromide). After $10 \mathrm{~min}$ at $65^{\circ} \mathrm{C}, 700 \mu \mathrm{l}$ of chloroform:isoamyl alcohol (24:1) was added and the mixture was placed on ice for 30 $\min$. After 10 min centrifugation at 14,000 $\times g$ at $4^{\circ} \mathrm{C}, 600 \mu \mathrm{l}$ of the supernatant was transferred to fresh microcentrifuge tubes containing $225 \mu \mathrm{l}$ of $5 \mathrm{M}$ ammonium acetate and placed on ice for $30 \mathrm{~min}$. Follow- 
ing a 10-min centrifugation at $14,000 \times g$ at $4^{\circ} \mathrm{C}$, the supernatant was added to 0.55 volume of isopropanol, mixed well, and incubated on ice for at least $10 \mathrm{~min}$. The mixture was centrifuged for $10 \mathrm{~min}$ at $14,000 \times g$ at $4^{\circ} \mathrm{C}$ and the supernatant was discarded. The DNA pellets were washed with $70 \%$ ethanol, dried, and resuspended in $100 \mu \mathrm{l}$ of sterile water. DNase-free RNase (Roche Diagnostic) was added (1 $\mu \mathrm{g})$, and the DNA extracts were incubated at $37^{\circ} \mathrm{C}$ for $20 \mathrm{~min}$. Some of the DNA extractions from infected cherries were done using the DNeasy Plant Mini Kit (Qiagen, Mississauga, ON, Canada). Extraction was performed on $0.1 \mathrm{~g}$ of infected fruit flesh following the manufacturer's protocol, and the DNA was eluted in a total volume of $100 \mu \mathrm{l}$ of AE buffer. DNA extracted from pure mycelia was quantified by running an aliquot along with known quantities of a DNA mass ladder (Invitrogen Life Technologies, Burlington, ON, Canada). DNA concentration was estimated by comparing the intensity relative to the DNA mass ladder band of the most comparable size.

DNA amplifications. RAPD reactions were performed using the GeneAmp kit (Applied Biosystems, Streetsville, ON, Canada). Approximately 20 to $25 \mathrm{ng}$ of DNA was amplified in $10 \mathrm{mM}$ Tris- $\mathrm{HCl}$, $\mathrm{pH} 8.3,50 \mathrm{mM} \mathrm{KCl}, 250 \mu \mathrm{M}$ of each dNTP, $1.5 \mathrm{mM} \mathrm{MgCl}_{2}, 1.2 \mu \mathrm{M}$ 10-mer random primer, and 0.5 units of Taq DNA polymerase (Invitrogen Life Technologies) for a total volume of $20 \mu \mathrm{l}$. The reactions were carried out in a Perkin-Elmer 9600 thermocycler (Applied Biosystems) with an initial denaturation at $94^{\circ} \mathrm{C}$ for $3 \mathrm{~min}$ followed by 35 cycles of $94^{\circ} \mathrm{C}$ for $5 \mathrm{~s}$, $35^{\circ} \mathrm{C}$ for $30 \mathrm{~s}$, a 2 -min ramping to $72^{\circ} \mathrm{C}$ $\left(0.3^{\circ} \mathrm{C} / \mathrm{s}\right)$, and an extension at $72^{\circ} \mathrm{C}$ for 2.5 min. After 35 cycles, there was a final extension at $72^{\circ} \mathrm{C}$ for $5 \mathrm{~min}$. The random primers RAPD screening were purchased from John Hobbs (Nucleic Acid Protein Services (NAPS) Unit, Biotechnology Laboratory, University of British Columbia, Vancouver, BC, Canada). Primers 308, 316, 322, 336, 346, 351, 353, 354, 356, $358,360,361,364,366,368,369,370$, 372,374 , and 375 were tested (Sequence available online from University of British Columbia, Biotechnology Laboratory).

The PCR reactions to recover the fragment corresponding to the 491-bp M. fructigena RAPD fragment in the other species were done as follows. Primers were designed from the $M$. fructigena sequence obtained from the cloned RAPD fragment. MO368-6R (5'-AGT TAT CGG CTT GGG AGC GG-3') and MO368-1 (5'-ACT TGT GCG GCA AAA GAG TA-3') (synthesized by Invitrogen Life Technologies) were used with the same conditions as for the species-specific multiplex PCR with the exception of an annealing temperature of $35^{\circ} \mathrm{C}$ for $M$. fructicola and M. laxa and $55^{\circ} \mathrm{C}$ for Monilia polystroma.
Multiplex PCR reactions using speciesspecific primers were performed using Invitrogen Life Technologies reagents. Approximately 10 to $50 \mathrm{ng}$ of DNA extracted from pure mycelia or 1:10, 1:30, or 1:100 dilutions of the DNA extracted from inoculated or infected fruits were amplified in $20 \mathrm{mM}$ Tris- $\mathrm{HCl}, \mathrm{pH} 8.4,50 \mathrm{mM} \mathrm{KCl}$, $200 \mu \mathrm{M}$ of each dNTP, $2.5 \mathrm{mM} \mathrm{MgCl} 2,0.2$ $\mu \mathrm{M}$ of each of the specific primers, and 0.25 units of Taq DNA polymerase (Invitrogen Life Technologies) in a total volume of $10 \mu \mathrm{l}$. The reactions were carried out in a PTC-200 DNA engine thermocycler (MJ Research, Watertown, MA) or a PerkinElmer 9600 thermocycler (Applied Biosystems), with an initial denaturation at $95^{\circ} \mathrm{C}$ for $2 \mathrm{~min}$ followed by 35 cycles of $95^{\circ} \mathrm{C}$ for $15 \mathrm{~s}, 60^{\circ} \mathrm{C}$ for $15 \mathrm{~s}$, an extension at $72^{\circ} \mathrm{C}$ for $1 \mathrm{~min}$, and at the end of the last cycle a final extension at $72^{\circ} \mathrm{C}$ for $3 \mathrm{~min}$. The specific primers (synthesized by Invitrogen Life Technologies) are: MO368-5 (common reverse primer) 5'-GCA AGG TGT CAA AAC TTC CA- ${ }^{\prime}$ and the three forward primers: MO368-8R (specific to M. fructigena and Monilia polystroma) 5'AGA TCA AAC ATC GTC CAT CT-3', MO368-10R (specific to M. fructicola) 5'AAG ATT GTC ACC ATG GTT GA-3', and Laxa-R2 (specific to M. laxa) 5'-TGC ACA TCA TAT CCC TCG AC-3'. Amplified products were electrophoresed through $1.5 \%$ agarose gels in $1 \times \mathrm{TBE}$ buffer, stained with ethidium bromide, and visualized under ultraviolet light.

Cloning and sequencing RAPD or PCR products. Selected amplified DNA products of the Monilinia species were isolated from agarose gels using a GeneClean II kit (Bio101, Qbiogene, Carlsbad, CA) following the manufacturer's protocol and ligated into the vector pBluescriptII $\mathrm{SK}+$ (Invitrogen Life Technologies). After transformation of Escherichia coli DH5 $\alpha$, white colonies were selected and plasmid DNA was prepared. Restriction digests were undertaken on plasmids to confirm the presence of an insert of the expected size, and these plasmids were then sequenced using the T7 Sequenase v2.0 Quick-Denature plasmid sequencing kit (Amersham Biosciences, Baie D'Urfé, QC, Canada) following the manufacturer's protocol. The PCR fragments obtained for Monilia polystroma were sent to Mobix Lab (McMaster University, Hamilton, ON, Canada) for direct sequencing. Sequence comparisons were done using DNASIS Ver 2.6 for Windows (Hitachi Software Engineering Co. Ltd., San Francisco, CA).

\section{RESULTS}

Screening for polymorphic RAPD patterns. Twenty random primers were used in RAPD reactions with $M$. fructigena, $M$. fructicola, and M. laxa DNA to find a polymorphic DNA band among the three species. RAPD patterns were characteristic for each pathogen. Using primer
368, a 491-bp fragment was amplified strongly from $M$. fructigena and not from M. fructicola and M. laxa (Fig. 1). This 491-bp fragment was chosen for its strong intensity and its size, which would facilitate characterization.

Characterization of the 491-bp $M$. fructigena RAPD fragment. The 491-bp RAPD fragment amplified from $M$. fructigena isolate ATCC 11790 (GenBank accession AF506701) was cloned for sequence analysis. From the sequence obtained, specific primers MO368-6R and MO368-1 were designed. MO368-6R contains the sequence just downstream of the primer 368 site at the $5^{\prime}$ end of the RAPD fragment, and MO368-1 contains all of the RAPD primer 368 sequence at the other end plus 10 bases upstream of the RAPD primer (Fig. 2). These primers designed from the $M$. fructigena sequence were used with M. fructicola, M. laxa, and Monilia polystroma DNA to produce PCR fragments from the same area of the genome for each of these species. A 620-bp PCR fragment from $M$. fructicola isolate DAOM 144721 and a 414-bp PCR fragment from $M$. laxa isolate LMK 723 were cloned and sequenced (GenBank accessions AF506700 and AF506702, respectively). A 504-bp PCR fragment from Monilia polystroma isolate CBS 102686 was directly sequenced (GenBank accession AY456197). A comparison of the sequences obtained from the four species

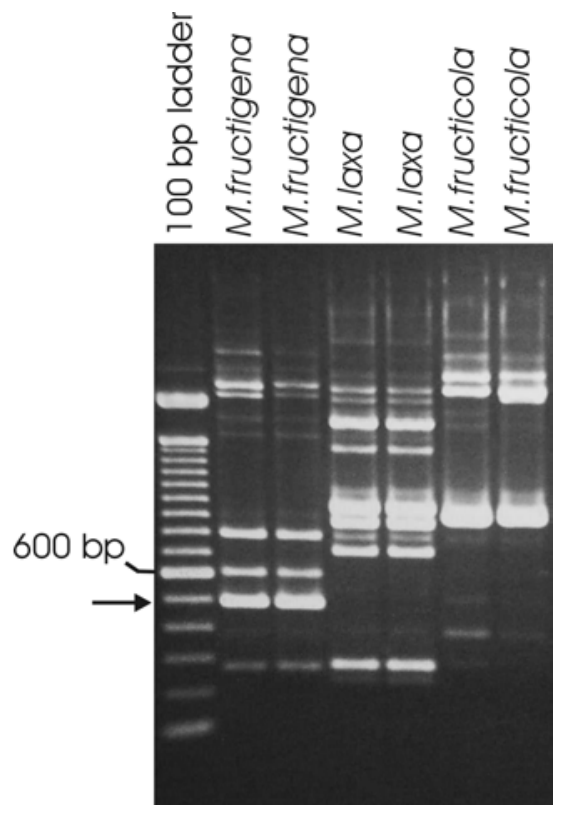

Fig. 1. Random amplified polymorphic DNA (RAPD) assay on selected isolates of Monilinia spp. using primer 368. Arrow on left indicates position of 491-bp RAPD fragment obtained for the $M$. fructigena isolates. Isolates used for $M$. fructigena are LMK 433 in lane 2 and LMK 434 in lane 3; for M. laxa, isolate LMK 656 in lane 4 and LMK 723 in lane 5; and for M. fructicola, isolate JN Mer3-4 in lane 6 and JN TC3-13 in lane 7. Sizes (base pairs) of selected fragments of the 100-bp ladder are indicated on the left. 
is presented in Figure 2. All three other species' sequences are very similar to the M. fructigena sequence for the last $33 \mathrm{bp}$ (Fig. 2, bases 583 to 615). Apart from two sections of approximately 40 bp each (Fig. 2, bases 449 to 490 and 527 to 568), there are no other significant similarities among the four sequences. Analysis of the sequences shows the Monilia polystroma sequence to be the closest to $M$. fructigena with $93 \%$ similarity. M. laxa is $72 \%$, similar to $M$. fructigena, whereas $M$. fruc- ticola is the most distant with $41 \%$ similarity due to several insertions (Fig. 2). At the $3^{\prime}$ end of the sequence, all four species share a common ATG codon (Fig. 2, bases 583 to 585) that initiates a stretch of 11 amino acids that is identical for all sequences. Using the BLAST search program (National Centre for Biotechnology Information), there were no obvious similarities with any of the sequences available in GenBank other than those in this study.
PCR analysis of Monilinia and Monilia species. Multiplex PCR analysis of Monilinia and Monilia species was carried out using primers MO368-8R, MO368-10R, and LaxaR-2 in combination with primer MO368-5. Primers MO3688R, MO368-10R, and LaxaR-2 were designed to bind specifically to the highly variable $5^{\prime}$ end region of the sequence for each Monilinia species. Primer MO368-5 corresponds to base pairs 584 to 603 at the $3^{\prime}$ end of the RAPD 368 fragment, located

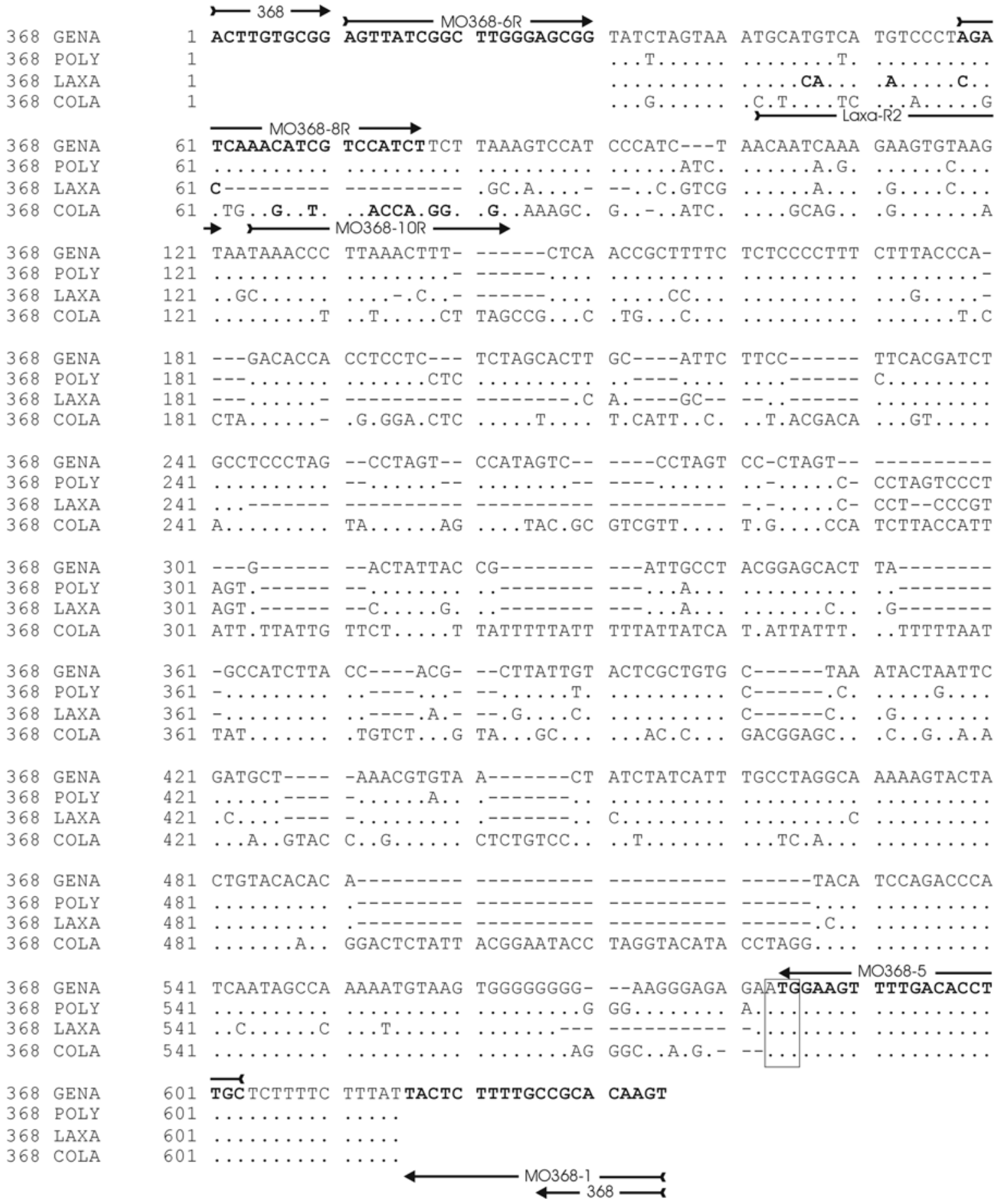

Fig. 2. Sequence alignment of the genome area corresponding to the Monilinia fructigena 491-bp random amplified polymorphic DNA (RAPD) product for the three Monilinia spp. and Monilia polystroma. Identical nucleotides are represented by dots, and absent nucleotides are shown by hyphens. Spaces at beginning and end of alignment are undetermined sequences. Primers used for polymerase chain reaction (PCR) assays and sequence analysis in this study are indicated in the sequence by bold letters and arrows indicating direction of amplication reaction. Putative translation initiation codon is boxed. 
within the portion of the alignment that is identical for all species (Fig. 2). Amplification using a mixture of all four primers produced a 402-bp PCR product for $M$. fructigena, a 535-bp product for $M$. fructicola, a 351-bp product for M. laxa, and a 425-bp PCR product for Monilia polystroma (Fig. 3). All Monilinia and Monilia isolates listed in Table 1 were tested with MO368-8R, MO368-10R, LaxaR-2, and MO368-5. Botrytis cinerea and Sclerotinia sclerotiorum were included in the study due to their close relationship with the three Monilinia species of this study (8). The results of the species-specific multiplex PCR are shown in Table 1. There were no PCR products for $B$. cinerea, $S$. sclerotiorum, or the four other Monilinia spp. listed in Table 1. A DNA fragment of the expected size was amplified for all isolates of $M$. fructigena, $M$. fructicola, and Monilia polystroma tested. All but three isolates of M. laxa amplified a PCR product of the expected size. Isolates CBS 165.24, DAOM 209913, and UAMH 3523 amplified a PCR product of a size corresponding to the size of the product for $M$. fructicola. Fungal primers ITS1 and ITS2 (20), which amplify across the internal transcribed spacer 1, the 5.8SrRNA, and the internal transcribed spacer 2, were used on these specific isolates to amplify a PCR fragment that was isolated and sequenced (data not shown). The sequences obtained for isolates CBS 165.24, DAOM 209913, and UAMH 3523 were compared with sequences published for $M$. fructicola, $M$. fructigena, and M. laxa $(8,10)$ and were found to be identical to the sequence for M. fructicola.

The Monilinia species DNA that did not yield a PCR fragment, as well as $B$. cinerea and $S$. sclerotiorum DNA, amplified a band of appropriate size with the ribosomal DNA primers NS5 and NS6 (20), demonstrating that DNA quality and quantity were not the reason for the absence of the specific PCR band (data not shown).

Detection of Monilinia and Monilia on inoculated apples. DNA was extracted from brown apple skin, brown flesh, brown apple skin and flesh together, and mycelia. Every sample taken from infected apples yielded the PCR fragment corresponding to the inoculated Monilinia or Monilia species. An example of the signal obtained for each species from DNA extracted from inoculated apple is shown in Figure 3.

Detection of Monilinia species from mixed inoculations. Apples were inoculated at two separate sites with one Monilinia species per site in a total of three experiments combining two of the three brown rot species of Monilinia per experiment. Rotting tissues surrounding each inoculated site located as far as possible from the other species were taken for DNA extraction. Rotting tissues located between the two inoculation sites were taken as well. Every tissue sample tested amplified the PCR fragment corresponding to the Monilinia species inoculated closest to the sampling site. Samples taken between two inoculation sites amplified PCR fragments corresponding to both inoculated Monilinia species. Results are shown in Figure 4.

Monilinia species identification from naturally infected stone fruits. Rotting tissues from stone fruits showing brown rot symptoms were tested with the multiplex PCR assay. In cases of fruits demonstrating more than one localized bruised area, a sample was taken from each bruised area on the same fruit. The samples taken from naturally infected fruits amplified a PCR fragment corresponding to either $M$. fructicola or M. laxa confirmed by culture isolation. Results are shown in Table 2.

\section{DISCUSSION}

With increasing importation and exportation of various fresh fruits worldwide, border surveillance becomes more and more challenging. Especially with fresh commodities that may be detained, timely methods for the identification of potential quarantine pests are an important tool for inspection agencies to deliver the rapid service so essential to the import and export industries. Molecular biology based methods are progressively providing the means for timely identification of quarantine plant pests (13). These methods can potentially be designed to directly and specifically identify the species infecting a commodity. Molecular methods based on the PCR technique will give results more rapidly than identification following isolation of the potential quarantine pests. The multiplex PCR method described herein does not necessitate isolation of the fungal agent and therefore significantly accelerates the identification process compared with methods based on quantitative characteristics.

When the fungal agent infecting a commodity is suspected to belong to the Monilinia or Monilia genera, the multiplex PCR described herein can be used as a qualitative method to further identify the species among the four most likely to occur on stone fruits. In a single tube reaction, a PCR band specific to one of the species will lead to the identification of the Monilinia species and Monilia polystroma. Absence of amplification is not considered to be a final identification result, and the use of universal primers binding to a conserved area of the fungi ribosomal gene can be used to assess DNA quality or quantity.

The sequence information obtained from the RAPD fragment of $M$. fructigena corresponding to sequences obtained from the other Monilinia and Monilia species seems to correspond to the junction between the $5^{\prime}$ end noncoding and coding sequences. This would explain the sequence similarity at the $3^{\prime}$ ends, allowing the use of a common reverse primer, and sequence dissimilarity at the $5^{\prime}$ ends, facilitating the amplification of a species-specific fragment. The high variability of the sequence at the $5^{\prime}$ end of the marker also allows the specific amplification of fungal DNA on fruit without interference from plant DNA. The

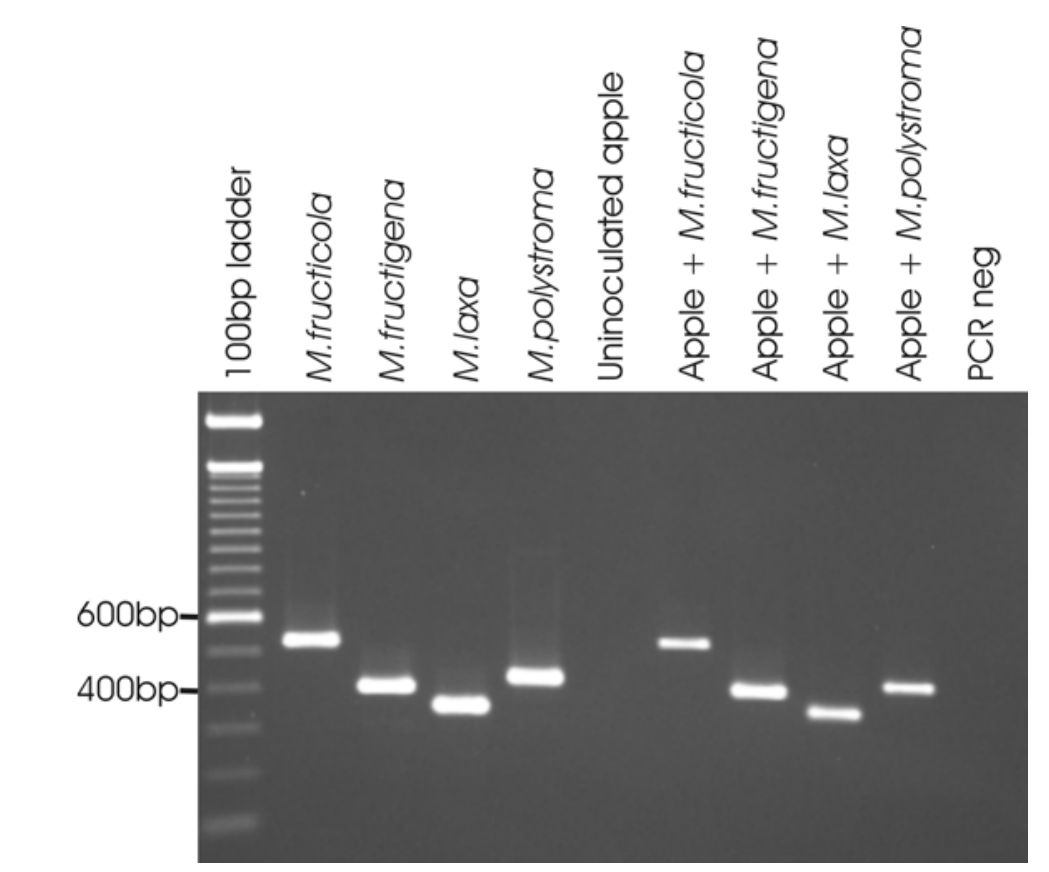

Fig. 3. Multiplex polymerase chain reaction (PCR) assay on selected isolates of the three Monilinia spp. and Monilia polystroma, from pure culture or from the rotting areas of inoculated apples. The isolate from pure culture used for M. fructicola is ATCC 42248, for M. fructigena ATCC 26106, for M. laxa ATCC 9961, and for Monilia polystroma CBS 102686. The isolate used to inoculate apples for M. fructicola is JN AN3-6, for M. fructigena ATCC 26106, for M. laxa ATCC 32671, and for Monilia polystroma CBS 102686. The last lane is a PCR negative control. Sizes (base pairs) of selected fragments of the 100-bp ladder are indicated on the left. 
multiplex method has been used to identify isolates from Monilinia-infected fruits in Uruguay and was proven to be effective in identifying $M$. fructicola (12).

To verify the specificity of the multiplex method, several isolates originating from varied sources were tested. The three isolates identified as $M$. laxa that produced bands specific to $M$. fructicola were likely misidentified. One of the isolates, UAMH 3523 , originated from the province of British Columbia, Canada, where M. laxa is known to occur. DAOM 209913 is suspected to originate from Uruguay, where
M. laxa was believed to be the most likely species to occur until recently (12). As for isolate CBS 165.24, Fulton and Brown (6) also placed the isolate in the $M$. fructicola group based on the amplification of a DNA fragment indicative of the presence of an intron in the SSU rDNA.

Recently, M. fructigena isolates originating from Japan were assigned to a distinct species, Monilia polystroma $(7,17)$. Three Monilia polystroma isolates were included in this study. Comparing the sequences of RAPD fragments from $M$. fructigena and Monilia polystroma confirmed

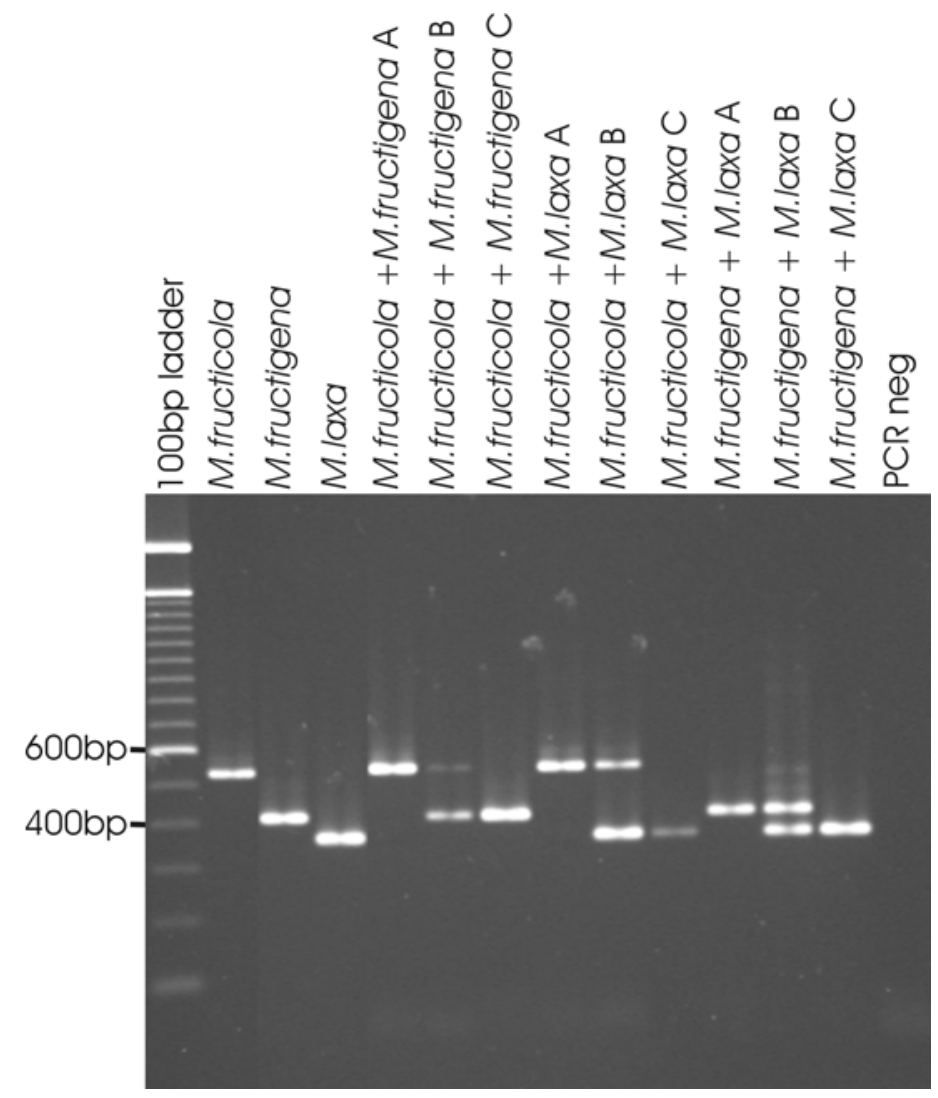

Fig. 4. Multiplex polymerase chain reaction (PCR) assay on selected isolates of the three Monilinia species from rotting areas of three inoculated apples. Apples were inoculated with $M$. fructicola JN AN3-6, M. fructigena ATCC 26106, and M. laxa ATCC 32671. Single inoculations for each species are shown in the first three lanes. The following nine lanes show mixed inoculations. The letters A, B, and $\mathrm{C}$ represent different samples taken from the same inoculated apple. A and $\mathrm{C}$ are samples taken from each side of the mixed inoculations and B are samples taken between the two inoculations. The last lane is a PCR negative control. Sizes (base pairs) of selected fragments of the 100-bp ladder are indicated on the left.

Table 2. Monilinia species identification directly from naturally infected fruits using multiplex polymerase chain reaction (PCR)

\begin{tabular}{llll}
\hline Sample no. & Infected fruit & Origin & ${\text { Monilinia } \text { species }^{\mathbf{a}}}$ \\
\hline M98-128 & Cherry & British Columbia, Canada & M. laxa \\
M98-129 & Cherry & British Columbia, Canada & M. fructicola \\
M98-130 & Cherry & British Columbia, Canada & M. fructicola \\
CPQP1 & Peach & Ontario, Canada & M. fructicola \\
CPQP3 & Nectarine & Canada & M. fructicola \\
MB00-06 & Cherry & Romania & M. laxa \\
MB00-07 & Cherry & Bulgaria & M. laxa \\
MB00-12 & Peach & British Columbia, Canada & M. laxa \\
MB00-13 & Cherry & British Columbia, Canada & M. laxa \\
MB00-14 & Cherry & British Columbia, Canada & M. laxa \\
\hline
\end{tabular}

a Monilinia species determined from DNA fragment size amplified using the multiplex PCR. that Monilia polystroma is indeed very closely related to $M$. fructigena but is sufficiently different to produce an amplicon of distinct size in the multiplex PCR method.

A procedure for the application of the multiplex method directly to infected fruit was established using inoculated apples. From these experiments, it was also shown that the multiplex PCR identified the two species present in mixed infection as long as tissue was collected from every infected area. This procedure is currently used for the identification of Monilinia species naturally infecting peaches, nectarines, and cherries submitted to our laboratory for testing. The Monilinia species identified so far on naturally infected fruits and presented in Table 2 are the species known to occur in Europe and Canada.

The multiplex PCR method described in this work has been demonstrated to be a relatively simple and rapid technique for identifying Monilinia and Monilia species known to infect stone fruits. The method can be universally used, because it identifies quarantined Monilinia and Monilia species occurring worldwide as well as $M$. laxa. Furthermore, the multiplex PCR method provides the basis for the future development of a quantitative and more sensitive PCR method using real-time PCR technology.

\section{ACKNOWLEDGMENTS}

We thank G. P. White and S. J. Miller for providing morphological identification and technical help. A special thanks to J. Northover in guiding us in the apple inoculation. We also thank L. M. Kohn, P. Mondino, and J. Northover for supplying isolates. We are grateful to C. Dollard, S. Hambleton, and S. Nadin-Davis for reviewing the manuscript. We also thank A. Saparno for technical help.

\section{LITERATURE CITED}

1. Batra, L. R. 1991. World species of Monilinia (fungi): Their ecology, biosystematics and control. Mycologia Mem. 16:1-246.

2. Boehm, E. W. A., Ma, Z., and Michailides, T. J. 2001. Species-specific detection of Monilinia fructicola from California stone fruits and flowers. Phytopathology 91:428-439.

3. Byrde, R. J. W., and Willetts, H. J. 1977. The brown rot fungi of fruit. Their biology and control. Pergamon Press, Oxford.

4. Côté, M.-J., Prud'homme, M., Meldrum, A. J and Tardif, M.-C. 2004. Variations in sequence and occurrence of SSU rDNA group I introns in Monilinia fructicola isolates. Mycologia 96(2):240-248.

5. Förster, H., and Adaskaveg, J. E. 2000. Early brown rot infections in sweet cherry fruit are detected by Monilinia-specific DNA primers. Phytopathology 90:171-178.

6. Fulton, C. F., and Brown, A. E. 1997. Use of SSU rDNA group-I intron to distinguish Monilinia fructicola from $M$. laxa and $M$. fructigena. FEMS Microbiol. Lett. 157:307-312.

7. Fulton, C. E., van Leeuwen, G. C. M., and Brown, A. E. 1999. Genetic variation among and within Monilinia species causing brown rot of stone and pome fruits. Eur. J. Plant Pathol. 105:495-500.

8. Holst-Jensen, A., Kohn, L. M., Jakobsen, K. S., and Schumacher, T. 1997. Molecular phylogeny and evolution of Monilinia (Sclerotiniaceae) based on coding and noncoding rDNA 
sequences. Am. J. Bot. 84:686-701.

9. Hughes, K. J. D., Fulton, C. E., McReynold, D., and Lane, C. R. 2000. Development of new PCR primers for identification of Monilinia species. Page 54 in: EPPO conference on diagnostic techniques for plant pests. Wageningen, NL, 2000-02-01/04.

10. Ioos, R., and Frey, P. 2000. Genomic variation within Monilinia laxa, M. fructigena and $M$. fructicola, and application to species identification by PCR. Eur. J. Plant Pathol. 106:373378.

11. Ma, Z., Luo, Y., and Michailides, T. J. 2003. Nested PCR assays for detection of Monilinia fructicola in stone fruit orchards and Botryosphaeria dothidea from pistachios in California. J. Phytopathol. 151:312-322.

12. Malvárez, G., Rodríguez, A., Aguilar, C., Silvera, E., y Mondino, P. 2001. Identificación de especies de Monilinia spp., en aislamientos obtenidos de Prunus spp. por PCR con primers específicos. Agrociencia V(1):48-53.
13. Martin, R. R., Delano, J., and Lévesque, C. A. 2000. Impacts of molecular diagnostic technologies on plant disease management. Annu. Rev. Phytopathol. 38:207-239.

14. Möller, E. M., Bahnweg, G., Sandermann, H., and Geiger, H. H. 1992. A simple and efficient protocol for isolation of high molecular weight DNA from filamentous fungi, fruit bodies, and infected plant tissues. Nucleic Acids Res. 20:6115-6116.

15. Penrose, L. J., Tarran, J., and Wong, A.-L. 1976. First record of Sclerotinia laxa Aderh. \& Ruhl. New South Wales: Differentiation from S. fructicola (Wint.) Rehm. by cultural characteristics and electrophoresis. Aust. J. Agric. Res. 27:547-556.

16. Snyder, C. L., and Jones, A. L. 1999. Genetic variation between strains of Monilinia fructicola and Monilinia laxa isolated from cherries in Michigan. Can. J. Plant Pathol. 21:70-77.

17. van Leeuwen, G. C. M., Baayen, R. P., Holb, I. J., and Jeger, M. J. 2002. Distinction of the asiatic brown rot fungus Monilia polystroma sp. nov. from $M$. fructigena. Mycol. Res. 106:444-451.

18. van Leeuwen, G. C. M., and van Kesteren, H. A. 1998. Delineation of the three brown ro fungi of fruit crops (Monilinia spp.) on the basis of quantitative characteristics. Can. J. Bot. 76:2042-2050.

19. Welsh, J., and McClelland, M. 1990. Fingerprinting genomes using PCR with arbitrary primers. Nucleic Acids Res. 18:7213-7218.

20. White, T. J., Bruns, T., Lee, S., and Taylor, J. 1990. Amplification and direct sequencing of fungal ribosomal RNA genes for phylogenetics. Pages 315-322 in: PCR Protocols. M. A. Innis, D. H. Gelfand, J. J. Sninsky, and T. J. White, eds. Academic Press, San Diego, CA.

21. Williams, J. G. K., Kubelik, A. R., Livak, K J., Rafalski, J. A., and Tingey, S. V. 1990. DNA polymorphisms amplified by arbitrary primer are useful as genetic markers. Nucleic Acids Res. 18:6531-6535. 